\title{
FACTORS INFLUENCING MORTALITY ASSOCIATED WITH THE TRANSLOCATION OF NORTHERN RIVER OTTERS (LONTRA CANADENSIS) IN UTAH
}

\author{
Casey C. Day ${ }^{1,2}$, Matthew D. Westover ${ }^{1}$, and Brock R. McMillan ${ }^{1}$
}

\begin{abstract}
Reintroductions and translocations of northern river otters have been a common management practice throughout the United States from the 1970s to the 2000s. Though many reintroductions have been successful, populations are not always monitored or evaluated post-release. From 2009 through 2012, we translocated 27 radio-marked otters into the Provo River watershed in northern Utah. Our objective was to determine what factors influenced the translocation-related mortality of otters. We developed a series of a priori models and used logistic regression to determine the most influential factors. We used Akaike's information criterion to evaluate relative model support. We found that the univariate model including body mass bore the most model weight and that body mass was the most important factor influencing the initial survival of translocated otters. Model-averaged $\beta$ estimates indicated that otters at the high end of body mass were 4 times more likely to survive the translocation than otters at the low end of body mass. Sex was the next most important factor influencing survival, as odds ratios indicated that males were more likely to survive the translocation than females. We urge ecologists and managers to delay the trapping and translocating of otters until young-of-the-year are likely large enough to have a high probability of survival. We further recommend female-biased translocations, as females were less likely to survive translocations.
\end{abstract}

RESUMEN.—La reintroducción y traslocación de las nutrias de río del norte fueron comunes en todo Estados Unidos desde los años setenta hasta la década del 2000. Si bien muchas prácticas de reintroducción fueron exitosas, no siempre se monitorea y/o evalúa a las poblaciones después de liberarlas. Entre el año 2009 y el año 2012, realizamos la traslocación de 27 nutrias de un determinado radio a la línea divisoria del Río Provo al norte de Utah. Nuestro objetivo fue determinar qué factores influyeronn en la mortalidad de las nutrias a causa del traslado. Desarrollamos una serie de modelos a priori y utilizamos la regresión logística para determinar qué factores tuvieron más influencia. Utilizamos el criterio de información de Akaike para evaluar el apoyo relativo del modelo y descubrimos que el modelo univariable que incluía la masa corporal registraba el peso máximo del modelo, y que la masa corporal fue el factor más importante que influyó en la supervivencia inicial de las nutrias a las que se había sometido a la traslocación. Las estimaciones $\beta$ promedio del modelo indicaron que las nutrias que se encontraban en el extremo más alto de los indicadores de masa corporal tenían cuatro veces más probabilidades de sobrevivir al traslado que las nutrias que se encontraban en el extremo más bajo. El sexo fue el siguiente factor más importante que influyó en la supervivencia, los índices de probabilidad indicaron que los machos tenían más probabilidades de sobrevivir el traslado que las hembras. Solicitamos a los ecologistas y a los encargados de cuidar el medioambiente que posterguen la colocación de trampas y el traslado de nutrias hasta que los juveniles sean lo suficientemente grandes como para tener una mayor probabilidad de supervivencia. Además, recomendamos no trasladar hembras, las cuales mostraron menos probabilidades de sobrevivir a las traslocaciones.

The northern river otter (Lontra canadensis) is a highly social (Reid et al. 1994, Gorman et al. 2006), usually nocturnal (Martin et al. 2010) carnivore that has undergone a number of reintroductions since the 1970s (Raesly 2001). Originally, its range extended east to west across North America and from Mexico to Alaska (Hall 1981, Polechla 1988, Melquist et al. 2003). However, during the 19th and 20th centuries, the northern river otter experienced a severe range contraction (Deems and Pursley 1978, Melquist et al. 2003), most likely due to unregulated harvest and habitat degradation (Polechla 1990). Following the recent trend toward species conservation (Seddon et al. 2007), however, the otter's range is once again expanding, with at least 22 states having conducted reintroduction projects since the 1970s. Some of these projects have been highly successful, providing evidence for longterm survival and reproduction (Serfass et al. 1993a, 1999).

Unfortunately, reintroductions are often unsuccessful due to poor planning and little or

\footnotetext{
${ }^{1}$ Department of Plant and Wildlife Sciences, Brigham Young University, 275 WIDB, Provo, UT 84602.

2E-mail: day29@purdue.edu
} 
no post-release monitoring. Reintroductions of carnivores are no exception, despite the common practice of reintroducing carnivores because of their substantial trophic impact (Estes and Palmisano 1974, Paine 1980, Beschta and Ripple 2011) and roles as symbols of conservation (Gittleman et al. 2001). One meta-analysis of 137 completed carnivore reintroductions revealed that only half were deemed successful, with 44 reporting failure and 24 reporting an unknown outcome (Breitenmoser et al. 2001). A failed reintroduction or translocation can still benefit the reintroduced species, however, if post-release monitoring reveals factors associated with reasons for the failure, such as cause-specific mortality. This information can include both immediate causes related to the translocation and general causes that would affect an established population. For river otters, incidental trapping and collisions with vehicles have been cited as common causes of mortality (Gorman et al. 2008, Serfass et al. 1993a). We were interested, however, in what factors might affect the survival rate of river otters during or immediately following translocation. Many otter reintroduction projects have experienced this type of premature mortality (e.g., Hoover et al. 1985, Kollias 1999, Spelman 1998), though no studies have examined the factors that might impact the likelihood of mortality.

Our objective was to determine what factors most influenced translocation-related mortality of northern river otters during a reintroduction conducted in northern Utah during 2009-2012. Specifically, we wanted to determine what biotic (e.g., age, sex, body mass) or abiotic (e.g., season, temperature) factors contributed to the translocation-related mortality of reintroduced individuals.

\section{METHODS}

We translocated 27 river otters from various locations in Utah and Idaho to the Provo River in Utah from November 2009 to January 2012. During the first year of the reintroduction, we trapped otters on an 8-mile section of the Green River below Flaming Gorge Dam in northeastern Utah. During the second year of the reintroduction, we trapped otters in coordination with the Utah Division of Wildlife Resources (UDWR) and Idaho Fish and Game (IDFG) on (1) Sheep Creek, which feeds the southwest corner of Flaming Gorge Reservoir, Utah; (2) Montour Wildlife Management Area, Idaho; (3) the Payette River near Garden Valley, Idaho; and (4) the IDFG Clearwater Region near the panhandle of northern Idaho. A few otters were also provided to us by private trappers from the Clearwater Region in exchange for a fee. During the third year of the reintroduction, trapping was conducted solely by IDFG, and otters were provided from the Clearwater Region. All but one otter was released into the middle section of the Provo River in the Heber Valley of northern Utah. The remaining otter was released in Provo Canyon just below the Heber Valley. This stretch of river was recently restored by the Utah Reclamation Mitigation and Conservation Commission and supports a diverse fish community (Nielson and Slater 2008, Billman et al. 2013). The area has not had a stable population of river otters since the 19th century, though otters have probably never been completely extirpated from the state (Maxfield et al. 2005).

To capture otters for translocation, we trapped at latrine sites, using Sleepy Creek \#11 long-spring leg-hold traps (Sleepy Creek Manufacturing, Berkley Springs, WV) supplemented by Victor \# 1 traps and Victor \# 1 softcatch traps (Oneida Victor, Inc., Cleveland, $\mathrm{OH})$. All traps that we used were modified (e.g., spaced jaws, double-jaws, padded jaws, inline springs and swivels) to reduce the risk of injury or discomfort to the otter. Once traps were in place, we monitored them each morning. All methods were approved by the Brigham Young University Institutional Animal Care and Use Committee (protocol 081101) and the Utah Division of Wildlife Resources. When an otter was caught, we followed several specific steps to ensure the successful capture and transportation of the animal using a Ketch-All pole and PVC transport tube (Serfass et al. 1993b). Once securely inside the tube, otters were transported to the ORCA Veterinary Facility at Brigham Young University.

In most cases, we transported otters to BYU the same day they were trapped, occasionally holding them overnight for logistical purposes or in anticipation of obtaining additional otters to transport the following day. We fed captive otters thawed fish and water, ad libitum, throughout their stay. BYU veterinarians chemically immobilized the otters with an intramuscular injection of ketamine (15 mg . 
$\left.\mathrm{kg}^{-1}\right)$ and midazolam $\left(5 \mathrm{mg} \cdot \mathrm{kg}^{-1}\right)$. While each otter was under anesthesia, veterinarians surgically inserted a radio-transmitter into the peritoneal cavity. The veterinarians also administered Convenia $\left(8 \mathrm{mg} \cdot \mathrm{kg}^{-1}\right)$, an antibiotic; Meloxicam (5 $\left.\mathrm{mg} \cdot \mathrm{mL}^{-1}\right)$, an analgesic; Ivermectin $\left(0.2 \mathrm{mg} \cdot \mathrm{kg}^{-1}\right)$, a parasiticide; and vaccines for distemper and clostridium. For more complete surgical methods, see Day (2012). We allowed the otters to recover naturally from anesthesia and released them on the river after a few hours to a few days, depending on the veterinarian's level of concern for the recovery of the otter. All otters that were released with a transmitter and included in the data set were deemed to be in good overall condition by the veterinarians.

We used logistic regression in program $\mathrm{R}$ (R Development Core Team 2011) to determine what factors were most associated with translocation-related mortality of river otters. We first developed 16 a priori models from a set of variables that included sex (12 males, 11 females), body mass (4.3-10.6 kg), occurrence of injury $(n=2)$, minimum average temperature at the release site $\left(6.1-38.6{ }^{\circ} \mathrm{C}\right)$, season $($ fall $=9$, winter $=12$, spring $=2)$, source population (Utah $=16$, Idaho $=7$ ), and number of days in captivity $(2-5 \mathrm{~d})$. For average minimum temperature, we used 2 weeks of data starting with the release date of the otter. We obtained these temperature data from the Utah State University Climate Center (http://climate.usurf.usu.edu/). No more than 2 variables were included in any model because we were restricted by sample size in the number of parameters we could estimate (Peduzzi et al. 1996). Due to the asymptotic nature of mammalian weights, we included a variable for body mass squared because we predicted it would yield a better linear fit than untransformed body mass. For the response variable, we considered as a successful release any otters that survived 2 weeks beyond the translocation date. We tested for multicollinearity among continuous variables in program $\mathrm{R}$ and did not include any 2 variables in the same model that had a Pearson's correlation coefficient greater than 0.6 or less than -0.6 . To test for independence of discrete variables, we used a chi-square test in the case of 2 discrete variables and a $t$ test in the case of one continuous and one binary discrete variable. Combinations of covariates therefore excluded from analysis include sex and body mass $(P=$ $0.030)$, source population and time in captivity $(P=0.002)$, and season and minimum temperature $(P<0.001)$. To evaluate relative model support, we judged models based on minimization of Akaike's adjusted information criterion $\left(\mathrm{AIC}_{c}\right)$ for small sample sizes (Akaike 1974, Hurvich and Tsai 1989, Burnham and Anderson 2002). We considered models within $2 \mathrm{AIC}_{c}$ units to be competing with the top model. To evaluate effect sizes, we used modelaveraged $\beta$ estimates for each parameter and calculated odds ratios.

\section{Results}

We captured and transported 27 northern river otters to Brigham Young University. However, only 23 otters (12 males, 11 females) underwent surgery to implant a radio-transmitter in the peritoneal cavity; therefore, only these 23 were included in the data set. Of those, 6 otters died as a result of complications related to the translocation. Two of the 6 died while under anesthesia: one while recovering from the anesthesia and the other while still in the preparatory stages of surgery. One otter was found dead one week after release and had suffered from severe peritonitis and a dehisced surgical site. The remaining 3 mortalities all occurred within 2 weeks of release but from unknown specific causes, although necropsy revealed that starvation was a potential factor.

Model selection resulted in 2 competing models within $2 \mathrm{AIC}_{c}$ units (Table 1). The top 2 ranked models were univariate, composed of body mass squared and sex, bearing $29.0 \%$ and $12.6 \%$ of the model weight, respectively. No other models were deemed to be "competing," as all had an $\mathrm{AIC}_{c}$ score $>2$. The variables for body mass and body mass squared were highly correlated $(r=0.99)$, and therefore we did not combine them into any single model. Further, because body mass squared explained more variation in the data than body mass, we excluded any models containing the body mass variable from analysis. Combined, the 2 competing univariate models containing body mass squared and sex bore $41.7 \%$ of the total model weight. Though the bivariate model comprised of body mass squared and sex was a competing model, it was excluded from the model set because sex and body mass 


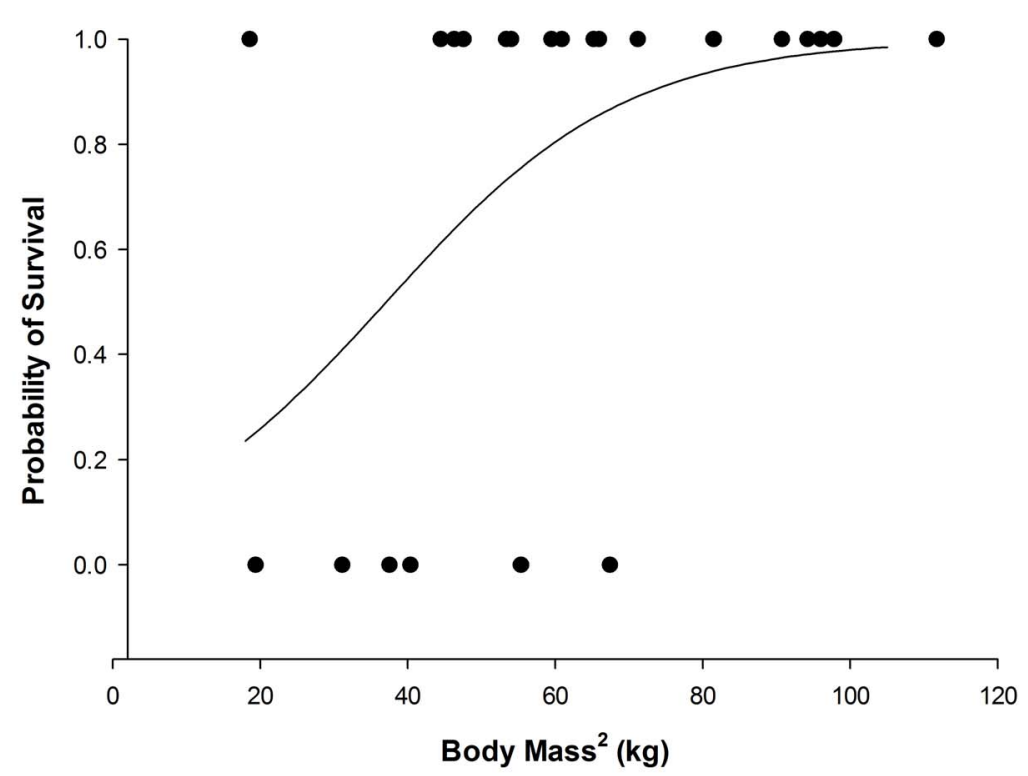

Fig. 1. Logistic regression function displaying the probability of river otter survival based on the square of body mass. Data were included from 23 river otters translocated to the Provo River, Utah, from November 2009 through January 2012 .

TABLE 1. Model structure and corresponding weights for factors influencing the mortality of river otters translocated to the Provo River, Utah, from November 2009 through January 2012. MinTemp is the mean temperature low for 2 weeks postrelease; TimeCap is number of days spent in captivity; Source is the source population, Utah or Idaho.

\begin{tabular}{|c|c|c|c|c|c|c|}
\hline Model & Parameters & $k$ & AIC & $\mathrm{AIC}_{c}$ & $\Delta \mathrm{AIC}_{c}$ & $w_{i}$ \\
\hline 18 & BodyMass $^{2}$ & 2 & 24.38 & 24.98 & 0.00 & 0.290389 \\
\hline 2 & Sex & 2 & 26.04 & 26.64 & 1.67 & 0.126245 \\
\hline 20 & BodyMass $^{2}$, Injury & 3 & 25.78 & 27.04 & 2.07 & 0.103249 \\
\hline 23 & BodyMass $^{2}$, MinTemp & 3 & 25.91 & 27.17 & 2.19 & 0.096993 \\
\hline 21 & BodyMass $^{2}$, TimeCap & 3 & 26.37 & 27.64 & 2.66 & 0.076795 \\
\hline 12 & Sex, MinTemp & 3 & 26.82 & 28.08 & 3.10 & 0.061537 \\
\hline 9 & Sex, Injury & 3 & 27.36 & 28.63 & 3.65 & 0.046789 \\
\hline 22 & BodyMass ${ }^{2}$, Season & 3 & 27.60 & 28.86 & 3.88 & 0.041685 \\
\hline 10 & Sex, TimeCap & 3 & 27.68 & 28.94 & 3.97 & 0.039971 \\
\hline 7 & MinTemp & 2 & 28.72 & 29.32 & 4.34 & 0.033090 \\
\hline 4 & Injury & 2 & 29.83 & 30.43 & 5.45 & 0.019043 \\
\hline 11 & Sex, Season & 3 & 29.54 & 30.80 & 5.83 & 0.015763 \\
\hline 1 & Source & 2 & 30.37 & 30.97 & 5.99 & 0.014501 \\
\hline 5 & TimeCap & 2 & 30.39 & 30.99 & 6.01 & 0.014357 \\
\hline 6 & Season & 2 & 30.95 & 31.55 & 6.58 & 0.010834 \\
\hline 17 & TimeCap, MinTemp & 3 & 30.72 & 31.98 & 7.00 & 0.008760 \\
\hline
\end{tabular}

were deemed not independent on the basis of a one-tailed $t$ test $(t=1.99, \mathrm{df}=21, P=$ $0.030)$. These results indicated that the most important variables correlated to the survival of otters over the initial 2 weeks were body mass squared and sex. Model-averaged $\beta$ estimates for these variables were $0.25(\mathrm{SE}=$ 0.030 ) and 2.2 (female was assigned 0 , male 1 , $\mathrm{SE}=0.099)$, respectively. When body mass was included, odds ratios indicated that males were 6.70 times more likely to survive the initial 2 weeks following translocation than females, although this statistic is likely inflated due to small sample size. According to the top model, probability of survival for otters on the high end of body mass (10.6 kg) was 99\%, 4.13 times higher than for those on the low end $(4.31 \mathrm{~kg}, 24 \%)$. The median body mass $(7.71$ $\mathrm{kg}$ ) was associated with an $80 \%$ probability of survival (Fig. 1). 


\section{Discussion}

Our findings indicate that body mass was the most important factor influencing the survival of translocated river otters, likely followed by sex. Despite the fact that we were unable to accurately age otters, these findings may show mortality to be linked to age, because age in otters is correlated with body mass. River otters gain weight rapidly during their first year and are 3-4 years old by the time they reach maximum length (Melquist and Hornocker 1983). Sexual dimorphism among the species may reveal why $83 \%$ of our mortalities were female, as female otters weigh less than male otters at all age classes (Jackson 1961, Melquist and Hornocker 1983). Sexual dimorphism may therefore explain why our top models were composed of variables for body mass and sex.

Though some otter reintroduction projects have no mortality associated with translocation events (Hernandez-Divers et al. 2001, Pitt et al. 2003, Spinola et al. 2008), this is not the case for the majority of reintroduction projects. In Oklahoma, 7 of 20 otters died either shortly after release or during holding (Hoover et al. 1985). In New York, 10 of 97 otters died while in transport or captivity (Kollias 1999). In Illinois, a total of 349 otters were translocated. Two of these otters died while under anesthesia, as well as 6 more soon after release (Bluett et al. 1999). Finally, in North Carolina, 76 of 333 otters died of various causes prior to being released (Spelman 1998). It should be noted that some of these studies did not monitor released otters, and other studies did not report mortalities of otters that died prior to being released. Therefore, in some cases, translocation-related mortality is potentially higher than has been reported here.

Though the previously mentioned studies do not provide data for sex and body mass of translocation-related mortalities, other findings have been consistent with the present study, with female and juvenile otters suffering the majority of translocation-related mortality. For example, in Pennsylvania, 84 otters were handled during 1982-1991, and 4 died while in captivity. All 4 otters were juveniles or yearlings (Serfass et al. 1993b). Also, one female from the Pennsylvania project died within 40 days of release (Serfass and Rymon 1985). In
Missouri, 3 of 29 otters died within 8 days of release, and all 3 of these mortalities were females (Erickson and McCullough 1987). In Tennessee, of 13 known otter fates, 3 were premature deaths: 1 subadult male and 2 adult females (Miller 1992). In New York, 4 of 69 otters (2 adult males, 1 juvenile female, and one adult female) died while in captivity. Three of these 4 otters weighed $<5 \mathrm{~kg}$ (Hartup et al. 1999), which in our study yielded a low chance of survival. Specific causes for these translocation-related mortalities vary widely, though across studies, common causes include exertional myopathy, inanition, parasitism, infection, and starvation. Regardless of specific causes and previously reported mortality, this study is the first to evaluate factors that may increase the general likelihood of translocation-related mortality. Our results, supported by published literature, indicate that juveniles and, to a lesser extent, females, are more susceptible than adult males. One factor involved may be that adult otters tend to have higher white blood cell counts, neutrophil counts, and monocyte counts than juveniles, indicating a greater compensatory immune response to stressful situations such as capture and transportation (Tocidlowski et al. 2000). Why females suffer higher mortality than males is less clear, but since females are often translocated during the period leading up to parturition, perhaps they have less energy available to compensate for stress in captivity.

Given this pattern of translocation-related mortality, it is possible to develop some guidelines about how and when to conduct river otter translocations. Clearly, it would be imprudent to move otters during denning season, when pups have yet to permanently emerge, are highly dependent on their mothers, and are not yet weaned. But with weaning occurring at around 12 weeks, how soon is too soon to begin trapping and translocating? Several of our otters died from unknown causes. It is possible, however, that these otters suffered from starvation as a result of being separated from their mothers prior to being capable of foraging independently. Starvation has been implicated in mortalities in other projects as well (Griess 1987, Miller 1992). Shannon (1991) showed that otters will provide food for their offspring for up to 8-9 months, at which point implantation could occur again. Though it may not be possible to establish a 
solid rule governing the timing of otter translocations, we recommend conducting translocations prior to and as near to denning season as possible, keeping in mind that implantation and gestation occur approximately 2 months prior to parturition. In Utah, this would mean translocations should occur in December-February to avoid causing stress to full-term females in March or April. This timing would vary by region, however, as reproductive cycles vary geographically in northern river otters (McDaniel 1963, Crait et al. 2006). In addition, we also recommend releasing related otters together to reduce the likelihood of starvation due to the inability of young otters to forage independently. We also urge managers of translocations to consider the guidelines that already exist for the proper trapping, handling, and clinical care of otters (Hoover et al. 1985, Serfass et al. 1996, Kollias 1999, Spelman 1999, Hernandez-Divers et al. 2001). Finally, we recommend that future otter translocations be female-biased, as females in our study were less likely to survive translocations than males.

Though body mass and sex had the most model support, it is also relevant to note which variables received relatively little support. Time spent in captivity, which has been shown to be a major factor for other species (Devineau et al. 2011), did not have an effect on otters, at least for up to 5 days, though other studies have reported lower mortality associated with longer captivity times (Spelman 1999). Likewise, the sustaining of minor injuries was not an important factor in the mortality of otters. However, it should be noted that some otters that sustained more serious injuries were selected to be released without a transmitter, and their fates therefore remain unknown. Finally, ambient temperature during the time of release was also found to not be an important factor in otter mortality, despite average minimum temperatures for some releases dipping below $-10{ }^{\circ} \mathrm{C}$. This is consistent with the Pennsylvania project that also released otters into cold temperatures with no related mortality (Serfass et al. 1996).

When conducting translocations for any species, it would be prudent to gauge what circumstances may result in a higher mortality rate. Other species, for example, have also shown a relationship between body mass/age class at release and survival (e.g., Menu et al. 2001, Hamilton et al. 2010, Bodinof et al.
2012, Buuveibaatar et al. 2013). The combination of multiple stressors can compound the risk of mortality. Otters, for example, were most vulnerable at low body mass (younger), but releasing otters of low body mass into areas with a relatively low prey base could compound the effect of low body mass. In any case, we encourage further investigations into the mortality of any species that, like the northern river otter, has been commonly reintroduced or translocated. Reintroductions can be an effective tool of conservation, yet all too often end in failure (Breitenmoser et al. 2001). By understanding and then limiting the effects of variables that can have a significant influence on the mortality of reintroduced individuals, likelihood of successful reintroductions will be maximized in the future.

\section{ACKNOWLEDGMENTS}

We thank Randy Larsen, Kevin Bunnell, and one anonymous reviewer for providing valuable feedback on an earlier version of this manuscript. Brigham Young University, the Utah Division of Wildlife Resources, Utah Wildlife in Need, and Idaho Fish and Game provided funding and support for the translocation. Andrew Shields's contribution was crucial to the trapping and transportation of otters.

\section{Literature Cited}

AKaIKe, H. 1974. A new look at the statistical model identification. IEEE Transactions on Automatic Control 19:716-723.

Beschta, R., and W. Ripple. 2011. Are wolves saving Yellowstone's aspen? A landscape-level test of a behaviorally mediated trophic cascade. Ecology 91: 2742-2755.

Billman, E.J., J.D. Kreitzer, J.C. Creighton, E. Habit, B.R. MCMillan, and M.C. BelK. 2013. Habitat enhancement and native fish conservation: can enhancement of channel complexity promote the coexistence of native and introduced fishes? Environmental Biology of Fishes 96:555-566.

Bluett, R.D., E.A. Anderson, G.F. Hubert JR., G.W. Kruse, and S.E. Lauzon. 1999. Reintroduction and status of the river otter (Lutra canadensis) in Illinois. Transactions of the Illinois Academy of Science 92: 69-78.

Bodinof, C.M., J.T. Briggler, R.E. Junge, T. Mong, J. Beringer, M.D. Wanner, C.D. Schuette, J. Ettling, and J.J. Millspaugh. 2012. Survival and body condition of captive-reared juvenile Ozark hellbenders (Cryptobranchus alleganiensis bishopi) following translocation to the wild. Copeia 2012: 150-159. 
Breitenmoser, U., C. Breitenmoser-Wursten, L.N. CarbYN, AND S.M. FunK. 2001. Assessment of carnivore reintroductions. In: J.L. Gittleman and S.M. Funk, editors, Carnivore conservation. University of Cambridge, Cambridge, United Kingdom.

Burnham, K.P., And D.R. Anderson. 2002. Model selection and multimodel inference: a practical information-theoretic approach. Springer, New York, NY.

Buuveibaatar, B., J.K. Young, J. Berger, A.E. Fine, B. LKhagVasuren, P. Zahler, and T.K. Fuller. 2013. Factors affecting survival and cause-specific mortality of saiga calves in Mongolia. Journal of Mammalogy 94:127-136.

Crait, J.R., G.M. Blundell, K.E. Ott, J.K. Herreman, AND M. BEN-DAVID. 2006. Late seasonal breeding of river otters in Yellowstone National Park. American Midland Naturalist 156:189-192.

DAY, C.C. 2012. Translocation mortality and local, regional, and continental diet of the northern river otter (Lontra canadensis). Master's thesis, Brigham Young University, Provo, UT.

Deems, E.J., AND D. Pursley. 1978. North American furbearers: their management, research and harvest status in 1976. University of Maryland, College Park, MD.

Devineau, O., T.M. Shenk, P.F. Doherty JR., G.C. White, AND R.H. KaHN. 2011. Assessing release protocols for Canada lynx reintroduction in Colorado. Journal of Wildlife Management 75:623-630.

ERICKSON, D.W., AND C.R. MCCullough. 1987. Fates of translocated river otters in Missouri. Wildlife Society Bulletin 15:511-517.

Estes, J.A., AND J.F. Palmisano. 1974. Sea otters: their role in structuring nearshore communities. Science 185:1058-1060

Gittleman, J.L., S.M. Funk, D.W. Macdonald, and R.K. WAYNE. 2001. Why 'carnivore conservation'? In: J.L. Gittleman and S.M. Funk, editors, Carnivore conservation. University of Cambridge, Cambridge, United Kingdom.

Gorman, T.A., J.D. Erb, B.R. McMillan, and D.J. MarTIN. 2006. Space use and sociality of river otters (Lontra canadensis) in Minnesota. Journal of Mammalogy 87:740-747.

Gorman, T.A., B.R. McMillan, J.D. Erb, C.S. Deperno, AND D.J. MarTin. 2008. Survival and cause-specific mortality of a protected population of river otters in Minnesota. American Midland Naturalist 159:98-109.

Griess, J.M. 1987. River otter reintroduction in Great Smoky Mountains National Park. Master's thesis, University of Tennessee, Knoxville, TN.

HaLL, E.R. 1981. The mammals of North America. Wiley, New York, NY.

Hamilton, L.P., P.A. Kelly, D.F. Williams, D.A. Kelt, AND H.U. Whitmer. 2010. Factors associated with survival of reintroduced riparian brush rabbits in California. Biological Conservation 143:999-1007.

Hartup, B.K., G.V. Kollias, M.C. JaCobsen, B.A. ValenTINE, AND K.R. KIMBER. 1999. Exertional myopathy in translocated river otters from New York. Journal of Wildlife Diseases 35:542-547.

Hernandez-Divers, S.M., G.V. Kollias, N. Abou-Madi, AND B.K. HaRTup. 2001. Surgical technique for intraabdominal radiotransmitter placement in North American river otters (Lontra canadensis). Journal of Zoo and Wildlife Medicine 32:202-205.

Hoover, J.P., R.J. Bahr, M.A. Nieves, R.T. Doyle, M.A. ZimMER, AND S.E. LaUZON. 1985. Clinical evaluation and prerelease management of American river otters in the 2nd year of a reintroduction study. Journal of the American Veterinary Medical Association 187: 1154-1161.

Hurvich, C.M., and C.L. Tsai. 1989. Regression and time-series model selection in small samples. Biometrika 76:297-307.

JaCKSON, H.H.T. 1961. Mammals of Wisconsin. University of Wisconsin Press, Madison, WI.

KolLias, G.V. 1999. Health assessment, medical management, and prerelease conditioning of translocated North American river otters. Zoo and Wild Animal Medicine: Current Therapy 4:443-448.

Martin, D.J., B.R. McMillan, J.D. Erb, T.A. Gorman, AND D.P. WALSH. 2010. Diel activity patterns of river otters (Lontra canadensis) in southeastern Minnesota. Journal of Mammalogy 91:1213-1224.

Maxfield, B., T. Bonzo, C. McLaughlin, and K. BunNELL. 2005. Northern river otter management plan. Utah Division of Wildlife Resources, Salt Lake City, UT.

MCDaniel, J.C. 1963. Otter population study. Proceedings of the Southeast Association of the Game and Fish Commission 17:163-168.

Melquist, W.E., AND M.G. Hornocker. 1983. Ecology of river otters in west central Idaho. Wildlife Monographs 83:3-60.

Melquist, W.E., P. Polechla, and D. Toweill. 2003. River otter. Lontra canadensis. Pages 708-734 in G. Feldhamer, B. Thompson, and J. Chapman, editors, Wild mammals of North America: biology, management, and conservation. Johns Hopkins University Press, Baltimore, MD.

Menu, S., G. Gauthier, and A. Reed. 2001. Survival of juvenile Greater Snow Geese immediately after banding. Journal of Field Ornithology 72:282-290.

Miller, M.C. 1992. Reintroduction of river otters into Great Smoky Mountains National Park. Master's thesis, University of Tennessee, Knoxville, TN.

Nielson, J.R., AND M.T. Slater. 2008. Deer Creek Reservoir fish population survey: 2007-2008. Utah Division of Wildlife Resources, Springville, UT.

PaINE, R.T. 1980. Food webs: linkage, interaction strength and community infrastructure. Journal of Animal Ecology 49:667-685.

Peduzzi, P., J. Concato, E. Kemper, T.R. Holford, and A.R. Feinstein. 1996. A simulation study of the number of events per variable in logistic regression analysis. Journal of Clinical Epidemiology 49: 1373-1379.

Pitt, J.A., W.R. Clark, R.D. Andrews, K.P. Schlarbaum, D.D. Hoffman, and S.W. PITT. 2003. Restoration and monitoring of the river otter population in Iowa. Journal of the Iowa Academy of Science 110:7-12.

Polechla, P. 1988. The nearctic river otter. Pages 668682 in W.J. Chandler and L. Labate, editors, Audubon Wildlife Report 1988/1989. Academic Press, San Diego, CA.

Polechla, P. 1990. Action plan for North American otters.

R Development Core Team. 2011. The R Project for Statistical Computing. R Foundation for Statistical Computing, Vienna, Austria.

Raesly, E.J. 2001. Progress and status of river otter reintroduction projects in the United States. Wildlife Society Bulletin 29:856-862.

Reid, D.G., T.E. Code, A.C.H. Reid, and S.M. Herrero. 1994. Spacing, movements, and habitat selection of 
the river otter in boreal Alberta. Canadian Journal of Zoology 72:1314-1324.

Seddon, P.J., D.P. Armstrong, and R.F. Maloney. 2007. Developing the science of reintroduction biology. Conservation Biology 21:303-312.

Serfass, T.L., R.P. Brooks, and L.M. Rymon. 1993a. Evidence of long-term survival and reproduction by translocated river otters, Lutra canadensis. Canadian Field-Naturalist 107:59-63.

Serfass, T.L., R.P. Brooks, T.J. Swimley, L.M. Rymon, AND A.H. HaYden. 1996. Considerations for capturing, handling, and translocating river otters. Wildlife Society Bulletin 24:25-31.

Serfass, T.L., M.J. Lovallo, R.P. Brooks, A.H. Hayden, and D.H. Mitcheltree. 1999. Status and distribution of river otters in Pennsylvania following a reintroduction project. Journal of the Pennsylvania Academy of Science 73:10-14.

Serfass, T.L., R.L. Peper, M.T. Whary, and R.P. Brooks. 1993b. River otter (Lutra canadensis) reintroduction in Pennsylvania, prerelease care and clinical evaluation. Journal of Zoo and Wildlife Medicine 24:28-40.

Serfass, T.L., AND L.M. Rymon. 1985. Success of river otter introduced in Pine Creek drainage in northcentral Pennsylvania. Transactions of the Northeast Section of the Wildlife Society 41:138-149.
ShannON, J.S. 1991. Progress on Californian otter research. Bulletin of the International Union for the Conservation of Nature Otter Specialist Group 6: 24-31.

Spelman, L.H. 1998. North American river otter (Lutra canadensis) translocation in North Carolina 19891996. Proceedings of the 2nd Scientific Meeting of the European Association of Zoo and Wildlife Veterinarians 1998:461-465.

1999. Otter anesthesia. Pages 436-443 in M.E. Fowler and R.E. Miller, editors, Zoo and Wild Animal Medicine: Current Therapy. Volume 4. W.B. Saunders Co., Philadelphia, PA.

Spinola, R.M., T.L. SERfass, and R.P. Brooks. 2008. Survival and post-release movements of river otters translocated to western New York. Northeastern Naturalist 15:13-24.

Tocidlowski, M.E., L.H. Spelman, P.W. Sumner, and M.K. Stoskopf. 2000. Hematology and serum biochemistry parameters of North American river otters (Lontra canadensis). Journal of Zoo and Wildlife Medicine 31:484-490.

Received 23 August 2012 Accepted 29 May 2013 